\title{
Representations of Madness in Irish Society in the Drama of BrianFriel
}

Michelle Kennedy

\section{(2) OpenEdition}

Journals

Electronic version

URL: https://journals.openedition.org/etudesirlandaises/3190

DOI: 10.4000/etudesirlandaises.3190

ISSN: 2259-8863

Publisher

Presses universitaires de Caen

Printed version

Date of publication: 30 October 2012

Number of pages: 113-127

ISBN: 978-7535-2158-2

ISSN: 0183-973X

\section{Electronic reference}

Michelle Kennedy, "Representations of Madness in Irish Society in the Drama of BrianFriel", Études irlandaises [Online], 37-2 | 2012, Online since 30 October 2014, connection on 27 July 2022. URL: http://journals.openedition.org/etudesirlandaises/3190 ; DOI: https://doi.org/10.4000/ etudesirlandaises.3190

This text was automatically generated on 27 July 2022.

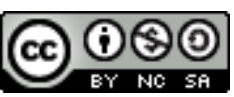

Creative Commons - Attribution-NonCommercial-ShareAlike 4.0 International - CC BY-NC-SA 4.0 https://creativecommons.org/licenses/by-nc-sa/4.0/ 


\title{
Representations of Madness in Irish Society in the Drama of BrianFriel
}

\author{
Michelle Kennedy
}

1 Madness and mental illness have been a prolifically recurrent theme in English literature worldwide. Lillian Feder in Madness in Literature contends that "recurrent literary representations of madness constitute a history of explorations of the mind in relation to itself, to other human beings, and to social and political institutions ${ }^{1 "}$. Yet while many texts investigate madness and mental illness on a global scale, this article seeks to explore the understanding and treatment of mental illness, particularly female mental illness, in a distinctly Irish context.

2 Through a study of female mentally ill characters in the drama of Brian Friel, it is possible to investigate the links between gender, societal pressures, repression and avoidance which dominate the attitude towards and treatment of mental illness in an Irish context. While it cannot be denied that causes and responses to mental illness in Ireland were, and are, manifold, this exploration will focus solely on the representation, agency and incarceration of Irish women as evidenced through the female characters in Friel's work. While significant gains have been made in the field of women's rights in Ireland from the latter half of the twentieth century right up to the present day, it is clear that certain groups, such as the mentally ill, are still excluded from the dominant hegemony and are effectively silenced within Irish society. By exploring mentally ill characters through the lens of theorists such as Louis Althusser, Michel Foucault and Martin Heidegger, changes in the representation of female characters can be analysed and the covert methods by which certain groups of women are subverted in Irish society can be unveiled.

\section{Madness and Mental IIIness in an Irish Context}

3 A report published in 2007 entitled Mental Health in Ireland: Awareness and Attitudes states that despite a promotion, in recent years, of "positive attitudes towards mental health issues", "a stigma still exists in relation to mental health in Ireland"." In fact: 
six in ten adults would not want people knowing about it if they themselves were experiencing mental health problems and a similar proportion do not believe that people with mental health problems should do important jobs such as being a doctor or a nurse ${ }^{3}$.

Irish society has traditionally avoided a true engagement with the issue of mental illness, repressing both the issue itself and the mentally ill, as harbingers of this issue. Friel himself outlines this conventional Irish strategy of avoidance when he states that the "Irish mind has many windows and the blinds are often down".

However, when one considers Ireland's dependence, in the early and mid twentieth century, on the institution, be it the mental institution, the reformatory school or the Magdalene Laundry, it is evident that Irish social and cultural attitudes towards the mentally ill are significant indices in exploring the Irish psyche and its response to the other. The fact that, as Mary Raftery points out, in the mid decades of the $20^{\text {th }}$ century, Ireland "led the world" in institutionalising "more people per capita" than any other country, points to a culture with an almost obsessive need to clearly distinguish, dehumanise and silence those who contravened the social mores of that time ${ }^{5}$. In 1958 the patient population in Ireland's mental institutions was over 21,000 and the Irish mental institutions were at their peak ${ }^{6}$. A considerable number of Friel's plays subtly engage with these issues, encapsulating Irish reactions to mental illness at a time when both mental illness and institutionalisation were very prevalent, if not prevalently discussed issues. This article will focus on three of these plays; The Loves of Cass McGuire (1966), Aristocrats (1990) and Molly Sweeney (1999), as significant works illuminating repression and institutionalisation of female mentally ill personages within an Irish cultural and geographical setting.

\section{Physical and Mental Repression of the Other}

Penfold and Walker have stated that "psychiatry functions as a form of social control... over and above its actual practises of treatment and incarceration?". This is an interesting theory to explore through the Irish lens. One could posit that psychiatry, coupled with an intrinsically Irish identification with, and feeling of, Catholic guilt, served as an effective means of social control in the latter half of the $20^{\text {th }}$ century. Psychiatry and psychiatric institutions could be seen as an Irish "Repressive State Apparatus". Althusser terms the Repressive State Apparatus as containing "the Government, the Administration, the Army, the Police, the Courts, the Prisons etc.", and as that which defines "the State as a force of repressive execution and intervention 'in the interests of the ruling classes ${ }^{8}$ "'. Psychiatry and psychiatric institutions function as Repressive State Apparatuses, simultaneously repressing, both physically and emotionally, those suffering from mental illness and making them invisible to a community and state which is unable or unwilling to engage with them.

7 The concept of Irish Catholic guilt operates in a similar manner as a cultural "Ideological State Apparatus". Althusser terms Ideological State Apparatuses as "the societal mechanisms for creating pliant, obedient citizens who practice dominant values $^{10}$ ". I would posit that a sense of guilt is inherent in the traditional Irish psyche and so functions as an agent of social control. Like all ideological state apparatuses, this guilt functions "predominantly by ideology", that is, presenting an image of the pure, chaste and obedient woman as a model of Irish citizenship, and "secondarily by 
repression", by instilling feelings of guilt and isolation from the family and community should this ideal be challenged or subverted ${ }^{11}$. Feder links this notion of guilt to mental illness when she makes the point that "[i]nappropriate, pathological guilt [...] was among the most common symptoms of mental disturbance prevalent in Western civilization so long as the authority of state, church, and patriarchal family was assumed $^{12 "}$.

Ireland of the late twentieth century can certainly be characterised as a country where deference to the church, state and patriarchal order was paramount. As such it is an ideal setting through which to study the way in which the Repressive and Ideological State Apparatus of psychiatry, institutionalisation and guilt combine to both publicly and privately isolate and silence a particular section of society who do not conform to normative societal values.

\section{Repression in the Drama of Brian Friel}

9 This theory is particularly applicable to Irish female characters in the drama of Brian Friel. Cass, in The Loves of Cass McGuire, Claire in Aristocrats and Molly in Molly Sweeney are prime examples of characters who encounter the Repressive and Ideological State Apparatuses of the institution and guilt and, as a result, are silenced, marginalised and, either directly or indirectly, institutionalised by Irish society. The mental disturbances that they suffer are either exacerbated or indeed directly caused by the restrictions placed upon them by the patriarchal order and societal dictates. As Anna McMullan states:

Friel's drama certainly critiques post-independence Ireland as a society stifled by a reified patriarchal authority and an economic, class and gender system reinforced and reproduced through the performative injunctions of "respectability" and status $^{13}$

10 Cass, in The Loves of Cass McGuire, is a character who encounters the Repressive and Ideological State Apparatuses of the institution and guilt, and both rails against and ultimately submits to these overbearing forces. Cass initially appears as a character who challenges pre-conceived notions of femininity; she has lived her life in America according to her own code of ethics, without regards for the societal or cultural boundaries within the Ireland that she had left. However upon her return, her choices and actions come under scrutiny within an Irish cultural context, a scrutiny under which her "strong and resilient" spirit is broken and she is eventually exiled to the institution of Eden House ${ }^{14}$.

11 Throughout the play Cass repeatedly states that "there will be no going back into the past!" (CM, 16). This unwillingness to look into the past can be linked to the guilt that she is made to feel about her life choices within an Irish cultural context. As the drama unfolds, Cass is forced to listen to comments about the unacceptability of her life in America that systematically strip away her self confidence, eventually forcing her to construct an alternative past life which is more acceptable within traditional Irish society. Dom, Cass's nephew, questions her about her living conditions in America, asking: "Did you live with Jeff Olsen, the man that owned the place you worked in, Auntie Cass? [...] Were you married to him? [...] Did you sleep with him?" (CM, 31).

12 Dom's particular line of questions subconsciously reminds Cass of how she has transgressed traditional sexual and moral conventions. Throughout the play she is 
reminded of this constantly by other characters. When Cass tells bawdy stories to the family they are shocked and Harry instantly reproaches Cass for her morally and socially unacceptable talk. The fact that she plans to tell these stories at her own welcome home party frightens and angers her family, as they fear being associated with the subversive force that Cass represents.

Tessa, the maid in Eden House, attempts to use religion and Cass's apparent lack of piety to make her feel ashamed for not being the quintessentially good Catholic woman. When Cass refuses to give Tessa a Christmas present bought for another resident, Tessa responds angrily, stating: "You dirty, mean aul' pagan! [...] Thanks be to God I was at Mass this morning" (CM, 35). This comment is intended to remind Cass of her non-conformity, to position her as an outsider, as other. Finally Pat Quinn's verbal attack on Cass, "[a] skivvy - that's what you were - written all over you! And a drunken aul' Skivvy, living in sin with a dirty aul' Yank that kicked you out in the end!" (CM, 49) is the last in a string of comments which finally break Cass' resilient spirit. Despite being an outspoken character at the beginning of the drama, she does not defend herself against his accusations, save for telling him to "Shut up" (CM, 49). The Ideological State Apparatus of guilt has stripped away Cass's self confidence and sense of self worth. Pat Quinn here is symbolic of the traditional male Irish Catholic patriarchal society which prescribed societal roles for women. Cass has transgressed these traditional roles and is made to feel guilt and shame as a result. Cass herself recognises that the reasons that she is considered dangerous, and thus marginalised, are bound up in Irish Catholic social and cultural mores. She tells Dom: "The less you see of your old Auntie Cass the better, because she ain't got no money, and we suspect she doesn't go to church, and we're not too sure if she's a maiden aunt at all" (CM, 16). Cass is the antithesis of the chaste, pure and silent Irish everywoman which the dominant hegemony promotes and rewards. As Andrews states, "Cass is the personification of a repressed, disruptive force which frightens and shocks the established order", and it is this fear of the other which sees Cass safely installed in Eden House, where she cannot challenge the dominant hegemony's view of women ${ }^{15}$.

Both Cass and her brother Harry's perspective and memories of the events surrounding Cass' institutionalisation is evidence of the attempt by those in power to manipulate the circumstances surrounding the silencing of the other. Interestingly, Harry states that Cass went to Eden House of her own accord, while Cass insists that her institutionalisation was not voluntary:

Harry: This isn't fair to us, Cass. It must be shown slowly and in sequence why you went to Eden House.

Cass: I didn't go, Harry boy, I was stuck in! (CM, 15)

Harry's attempt to present Cass's institutionalisation as something of her own making can be linked to Michel Foucault's assertion that '“Truth' is linked in a circular relation with systems of power which produce and sustain it ${ }^{16 " . ~ H a r r y, ~ a s ~ a ~ m e m b e r ~ o f ~ t h e ~}$ patriarchal dominant hegemony, posits a particular remembrance of the past in order to present an alternative truth that supports Cass' marginalisation within the institution. Cass "speaks for the submerged, unruly, female energies that the mainstream culture, represented by Harry, wishes to censor, marginalise or silence ${ }^{17}$ ". These energies must be suppressed in order to maintain the status quo and so Cass is sent into exile in Eden House. Harry presents his perception of events as the 'reality' of the dominant hegemony, a reality which Cass rebels against. Friel's use of the theatrical medium is crucial here to present Cass's particular form of rebellion; Cass's only 
method of rebellion against the dominant hegemony is to, as Anna McMullan states, disrupt "the middle-class/realist script" by establishing "a direct connection with the audience ${ }^{18 "}$. This direct communication with the audience and attempt to disrupt the linear movement of the play highlights Cass's ultimately futile attempt to regain a voice and agency within the dominant social order.

Cass' mental illness, manifested in her gradual escape from reality and recreation of her past, represents a submission of the subversive feminine to the Ideological State Apparatus of guilt. The aspects of her past that she changes in her delusional state are significant. She moves from living unmarried with Jeff to marrying Mr. Jeff Olsen in the presence of her family and friends, from being less well off to moving "into this great ten-roomed apartment on the West side" and from being the ignored and scorned Aunt Cass to being visited by Harry's children "as regular as the clock" (CM, 65; 66). Cass's delusion recreates a past within which she is acceptable and accepted by family and Irish society at large. In order to survive, she must conform, even if this conformity is indeed a lie. As Andrews states, Cass:

ends by embracing the values which Harry asserts against her at the beginning. [...] As she becomes absorbed in her 'rhapsody', her language is sanitised, her vibrant humour disappears. Her retreat from reality to 'rhapsody' renders the frightening, submerged forces of personality no longer threatening to the institutionalised order. They are now formalised, tamed, 'civilised' [...] Her survival is, in fact, a defeat ${ }^{19}$.

17 In effect, the combination of the Ideological State Apparatus of moral Catholic guilt, and the Repressive State Apparatus of the institution, has completely suppressed Cass's independent, effervescent personality.

The issue of traditional societal roles for women, and the guilt associated with transgressing these roles, is also highlighted in Friel's play Aristocrats. Claire, the youngest of the O'Donnell children, suffers from depression. This depression can be linked hereditarily to her mother's depression, but can also be linked to the repression by her father of her musical career and, by extension, her possibility of an independent life. Casimir, her brother explains her situation to Tom:

Casimir: '...on her sixteenth birthday she got a scholarship to go to Paris. But Father - you've met Father?

Tom: Actually I -

Casimir: 'An itinerant musician? (wagging finger.) Ho-ho-ho-ho-ho.' Wasn't that naughty of him ${ }^{20}$ ?

Judge O' Donnell's main concern with allowing Claire to undertake her scholarship was the perceived shame that it would bring to have an "itinerant musician" in the family (A, 259). Thus Claire's musical voice is silenced to the world at large and she must content herself with playing for her family and teaching some of the local children. Her repression by patriarchal society, symbolically represented by her father, is so complete that Claire becomes fully convinced of her own lack of ability and talent. As she tells Tom, "I'm only a good pianist. I'm not a great pianist. I thought I was once. But I know I'm not" (A, 274). Claire has internalised the guilt associated with her musical ambitions and what emerges is a deeply confused and unhappy woman, who now conforms to the status quo by getting married and fulfilling the traditional role of housewife and mother. But this outward conformity masks an inner turmoil, which she vocalises to Eamon, telling him "I'm in a mess...I don't know if I can go on with it" (A, 
291). Just like Cass, Claire is made to feel ashamed of herself, her choices and desires. Brown makes the point that in Friel's theatre:

individual characters are beset by manifold difficulties when they seek to define themselves as anything other than members of a family or of a markedly local community. The society in which they live, move and have their being affords little or no civic space for such self-expression [... $]^{21}$.

Both Claire and Cass's situation illustrates this point. Both characters have their selfexpression stifled and are subjugated to a patriarchal dominated society when they try to define themselves as an individual, outside of the family and community dynamic. Both are made to feel shame and guilt for their self-expression and identity and both, to varying degrees, are institutionalised. However, while Cass is exiled to the institution, the quintessential Repressive State Apparatus, Claire is repressed in a far more subtle manner.

While not officially institutionalised in a mental institution, it can be argued that Claire is institutionalised within her own home. This sense of imprisonment is evident in the level of control that is exerted over Claire's life in Ballybeg Hall. She has no distinct purpose, an aspect of her life which exacerbates her depression. Her decisions and actions are in many ways controlled by others. Each day Judith invents "some light work for her to do, just to jolly her along" (A, 299). Her own attempt to take up employment outside the home, teaching the village children music, fails because of the onset of a depressive episode, making her more dependent on the family and ever more isolated and institutionalised within the family home. Even some of the simplest decisions that Claire makes in the drama are controlled by others. When she is offered a drink by Eamon, she explains that the "doctor doesn't allow" her "to take alcohol when [she's] on sedatives" (A, 276). Eamon's sardonic reply, "Aren't you a wise and obedient girl" situates Claire as the repressed, powerless individual, who automatically responds in an acceptable manner, without regard for her own desires (A, 276).

Even Claire's choice of music throughout the drama reflects her repressed nature. She plays sonatas, ballades and waltzes by Chopin, remaining within the acceptable musical boundaries outlined by her father. In the same way that her mother regulated the music that she played in her husband's presence, Claire subconsciously adopts a delineation of the boundaries of acceptable self-expression. As McMullan postulates, the play "specifically dramatizes the inscription on subjected bodies of familial and institutional authority, that of the father/district judge, and that of the Big House itself ${ }^{22}$ ". It is only after Father's funeral that the song "Sweet Alice", her mother's favourite, is permitted to be sung in the house. Andrews makes the point that this "singing is a final gesture of defiance against the old order of the deceased Father", although it is interesting to note that it is only Casimir, Eamon and Alice who sing the song, Claire only humming in the background ${ }^{23}$. Even after the death of the patriarchal order the vestiges of the guilt remain, and Claire is unable to break free entirely from the boundaries of acceptable self-expression that have been outlined for her all her life. This is evident in Claire's plans for the future. Instead of moving toward a more independent life in the aftermath of her father's passing, Claire ends the play anxiously awaiting her marriage. Arguably she will move from one controlling institutional home to another. Having no financial independence or career, Claire's ability to carve out an independent existence within 1970s Irish society is highly questionable, serving to exacerbate her depression. This can be linked to Busfield's assertion that "women's position in society may be particularly conducive to madness and mental disorder ${ }^{24 "}$ ". 
The question remains, had Claire been given the freedom to pursue a musical career and maintain an independent existence, would she have suffered from depression so severely?

Finally, Molly Sweeney is another female character in Friel's work who is labelled as other and incarcerated, both mentally and physically, by patriarchal Irish society. Indeed Molly Sweeney is a significant play through which to study the effects of patriarchy and the dominant hegemony on the female within the Irish context, as through it Friel "directly stages the performance of male authority on the female body ${ }^{25 "}$. Her blindness is targeted by her husband Frank and Mr. Rice, an ophthalmologist, as something to be repaired in order to normalise Molly and enable her to have what they term a full life. This attempt to normalise Molly ends in disaster, mental breakdown and institutionalisation. Even though as Mr. Rice states Molly "had a full life and never felt at all deprived" by her disability, successive comments and questions posed to Molly function to subconsciously posit her as other. Throughout her life Molly was asked by various doctors to compare her world with the world she would share with them if she "had visual perception as well ${ }^{26 "}$. This presents Molly with a very delineated "us versus them" scenario, with the doctors representing normalcy and Molly taking up the role of the abnormal other. Indeed, Frank's excitement upon hearing that an operation is possible further illustrates this point: "if there is a chance, any chance, that she might be able to see, we must take it...What has she to lose? Nothing!" (MS, 459).

24 Frank implies that Molly is an incomplete person as a blind woman. He classifies this opportunity as "a new life for both of us" (MS, 467). These comments combine to make Molly feel like a burden, a problem to be fixed, and in so doing function as an Ideological State Apparatus to turn a vibrant, confident person into a silent and submissive woman. Molly's submission to this patriarchal pressure is evident when she considers the reasons for undertaking the operation:

Why am I going for this operation? None of this is my choosing. Then why is this happening to me? I am being used [...] And have I anything to gain? [...] suddenly I knew why I was so desolate. It was the dread of exile, of being sent away (MS, 472; 473).

Molly's anger at being exploited is superseded by the fear of being exiled by Irish society for non-compliance. Her desires therefore become intrinsically linked with what is expected of her by the patriarchal order symbolised by Frank and Mr. Rice. This becomes clear from Molly's initial hopes for the operation. Her own desire to see becomes secondary to that of pleasing the men:

If I had any hope, I suppose it was that neither Frank nor Mr. Rice would be too disappointed because it had all become so important for them (MS, 483).

Molly becomes a "lab rat" of sorts, passed from specialist to specialist, spending "months being analysed and answering questions" (MS, 496). Her worth as a person becomes intrinsically linked with her ability to conform to the sighted world both physically and mentally. Molly is thus mentally institutionalised by the medical tests that surround her every waking moment. She is tested in the hospital by specialists and upon returning home she is repeatedly questioned and tested by Frank, "As soon as tea was over [...] he'd begin my lesson" (MS, 491). This mental institutionalisation proves to be overwhelming and, as the drama moves forward, Molly's inability to conform to the 
"normal" sighted world signals a mental breakdown and a complete repression of her independent, vivacious nature.

Molly's internment in the mental institution is a movement beyond the mental institutionalisation of the medical tests. Having failed to integrate into sighted society, Molly is, in a strict sense, of no further use to Frank and Mr. Rice and so is exiled to the institution. The institution functions here as the Repressive State Apparatus, punishing Molly for her inability to conform, and intervening "in the interests of the ruling classes": by allowing both Frank and Mr. Rice to escape their guilt and incarcerate the victim of their failed experiment. Molly's presence in the community serves as a reminder to all of the detrimental effect of patriarchal order on traditional Irish society and, as such, must be removed from society's gaze. This point is further illustrated by Ussher who makes the point that women tend to be positioned as mad and sees this as a product of misogyny which silences women and renders them powerless ${ }^{27}$. Molly's powerlessness and silence is evident in her portrayal within the institution, where she is prized for her submissiveness. The nurse describes her as "a lovely woman. No trouble at all. If they were all as nice and quiet" (MS, 506). Molly is now a pliant and obedient citizen, conforming to the aspirations of the nurses in the mental institution in the same way that she had attempted to conform to the aspirations of Frank and Mr. Rice. If as Heidegger asserts, "language is the house of being", the silencing of Molly, in much the same manner as the silencing of Cass and Claire, is significant: the repression of their voice, their language, signals a negation of their very identity ${ }^{28}$.

It is evident from the treatment of characters in Friel's drama that adherence to traditionally acceptable modes of behaviour and societal values were essential to social acceptance within the Ireland of the mid to late twentieth century. However the question remains, in the twenty-first century, which has arguably seen the advent of an unsubscribed Irish society - freer from religious, political and societal control and subversion than any of the generations that preceded it, have Irish women, and indeed Irish people in general, succeeded in breaking down the discourse of the dominant hegemony and living a life free of cultural and societal assumptions, guilt and Repressive State Apparatuses? The answer, it seems, is contradictory. While institutions such as the Catholic Church and the government are currently being criticised and scrutinised more closely than ever before, it seems that Irish attitudes are slow to change in relation to freedom of expression. For example, one thousand face to face interviews were conducted around Ireland in 2007 for the report entitled Mental Health in Ireland: Awareness and Attitudes ${ }^{29}$. When questioned on the issue of "attitudes to living in Irish society today" the research concluded that "more people tend to agree that "People were better off in the old days when everyone knew how they were expected to act ${ }^{30}$ '”. A startling $31 \%$ of people under 35 and $53 \%$ of people 35 and older agreed either strongly or slightly with this statement ${ }^{31}$. These figures seem to signal an inner resistance to the advent of freedom of expression in modern Irish society. Whereas Irish people have broken down the barriers of many traditional Repressive and State Apparatuses that outlined acceptable modes of behaviour and repressed those who transgressed, it seems that the Irish psyche is unprepared to live entirely outside these spheres of influence. In this respect, the prevailing dominance of Repressive and Ideological State apparatus' in Irish society is clearly evident.

Within an Irish temporal and geographical context, identity is regulated and controlled, and those identities which do not conform to social and cultural mores are 
repressed and exiled through the use of Repressive and Ideological State Apparatuses. These, as can be seen from the evidence presented, can be applied directly, as in the case of the institutionalisation of Cass and Molly in The Loves of Cass McGuire and Molly Sweeney, or equally in the marital, familial and societal incarceration in the home as evidenced in Aristocrats. In Friel's drama, as McMullan asserts, women's bodies function "as conduits to the unconscious or to repressed areas of individual or cultural history ${ }^{32 "}$ ".

Guilt comes to the fore as a powerful Ideological State Apparatus in an Irish context, simultaneously punishing the transgressors while assuring the dominant hegemony of its moral superiority. In this way, as Heidegger asserts, the possibilities of "Being are disclosed and regulated ${ }^{33}$ ". This too has significant implications in relation to the postfeminist movement, which seeks to highlight previously repressed discourses. Friel's portrayal of and focus on female mental illness and the regulation of the female body within an Irish context provides an insight into the position and agency of dispossessed female groups such as the mentally ill. These women become part, as Cixous contends, of "the imund (l'immonde)", "the unclean", or "that which is rejected from the world ${ }^{34}$ ". This positing of the subversive female as mentally ill, and the ensuing rejection of the "unclean" through mental and/or physical incarceration, can be linked to Foucault's assertion of the "Relations of Power" as organisations that "are created to freeze the relations of power, hold those relations in a state of asymmetry, so that a certain number of persons get an advantage, socially, economically, politically, institutionally ${ }^{35 "}$.

31 Therefore, by using its power to shape dominant ideologies in modern culture, the dominant hegemony posits alternate views on society and culture as other, as abnormal. By positing these female characters as mentally ill, the dominant hegemony attempts to negate their voice. This is evident in the cultural and societal boundaries of acceptable modes of being which are traditionally strong in Ireland. Freedom of expression, or expression of dissatisfaction with the societal roles of the day was, and arguably remains, problematic. Those who expressed dissatisfaction could be exiled, and one particular method of marginalisation was to posit an individual as mad. I would postulate that the exploration of mentally ill characters in Friel's drama allows the position and agency of the marginalised in Irish society to be evaluated. In order to assess the exile of the marginalised in Irish society "the power of truth" must be detached "from the forms of hegemony, social, economic and cultural, within which it operates at the present time ${ }^{36 "}$. Only when this is achieved, can the marginalised be centralised in a modern Irish context.

\section{NOTES}

1. Lillian Feder, Madness in Literature, Princeton, Princeton University Press, 1980, p. 4-5.

2. Health Service Executive, Mental Health in Ireland: Awareness and Attitudes [online], available at: [ 
http://www.healthpromotion.ie/uploads/docs/HSP00612.pdf

], 2007, p. 6-12.

3. Ibid., p. 12.

4. Peter Lennon, "Playwright of the Western World", P. Delaney, (ed), Brian Friel in Conversation, Ann Arbour, University of Michigan Press, 2000, p. 22.

5. Mary Raftery, "Revealing the horrific past of psychiatric hospitals" Irishtimes.com [online], 5 Sept 2011: [

http://www.irishtimes.com/newspaper/opinion/2011/0905/1224303499645.html

] [accessed 5 Nov 2011].

6. Mary Raftery, op. cit.

7. Susan Penfold \& Gillian Walker, Women and the Psychiatric Paradox, Milton Keynes, Open University Press, 1984, p. 8.

8. Louis Althusser, "From Ideology and Ideological State Apparatuses", Vincent B. Leitch, (ed), The Norton Anthology of Theory and Criticism, New York \& London, W.W. Norton \& Company, 2001, p. 1489-1487.

9. Ibid., p. 1489.

10. Vincent B. Leitch, "Introduction", Vincent B. Leitch, (ed), The Norton Anthology of Theory and Criticism, New York \& London, W.W. Norton \& Company, 2001, p. 477.

11. Louis Althusser, op. cit., p. 1490.

12. Lilian Feder, op. cit., p. 5.

13. Anna McMullan, "Performativity, unruly bodies and gender in Brian Friel's drama", Anthony Roche (ed), The Cambridge Companion to Brian Friel, Cambridge, Cambridge University Press, 2006, p. 143.

14. Brian Friel, The Loves of Cass McGuire, Meath, The Gallery Press, 1992, p. 14. Henceforth this play will be referenced in the body of the text.

15. Elmer Andrews, The Art of Brian Friel: Neither Reality Nor Dreams, New York, St. Martins Press, 1995, p. 96.

16. Michel Foucault, "Truth and Power". In Vincent B. Leitch, (ed), The Norton Anthology of Theory and Criticism, New York \& London, W.W. Norton \& Company, 2001, p. 1669.

17. Elmer Andrews, op. cit., p. 97.

18. Anna McMullan, op. cit., p. 147.

19. Elmer Andrews, op. cit., p. 102-103.

20. Brian Friel, “Aristocrats”, Brian Friel: Plays 1, London, Faber and Faber, 1996, p. 259. Henceforth this play will be referenced in the body of the text.

21. Terence Brown, “'Have We a Context?': Transition, Self and Society in the Theatre of Brian Friel", Alan Peacock, (ed), The Achievement of Brian Friel, Buckinghamshire, Colin Symthe, 1993, p. 192.

22. Anna McMullan, op. cit., p. 149.

23. Elmer Andrews, op. cit., p. 157.

24. Joan Busfield, Men, Women and Madness: Understanding Gender and Mental Disorder, Basingstoke, Macmillan, 1996, p. 5.

25. Anna McMullan, op. cit., p. 145. 
26. Brian Friel, Molly Sweeney, Brian Friel: Plays 2, London, Faber and Faber, 1999, p. 465. Henceforth this play will be referenced in the body of the text.

27. Jane Ussher, Women's Madness: Misogyny or Mental Illness?, Essex, Prentice Hall, 1991, p. 7.

28. Heidegger, M., "Letter on Humanism" In D. F. Krell, (ed), Basic writings from Being and time (1927) to The task of thinking (1964), London, Routledge \& Kegan Paul, 1978, p. 213.

29. Health Service Executive, Mental Health in Ireland: Awareness and Attitudes [online], available at: [

http://www.healthpromotion.ie/uploads/docs/HSP00612.pdf

], 2007, p. 7.

30. Ibid., p. 25.

31. Ibid.

32. Anna McMullan, op. cit., p. 144-145.

33. Martin Heidegger, Being and Time, Oxford, Blackwell, 1962, p. 41.

34. Hélène Cixous, Sarah Cornell et al., Three Steps on the Ladder of Writing, New York, Columbia University Press, 1994, p. 117.

35. Michel Foucault, "Power, Moral Values, and the Intellectual, An interview with Michel Foucault by Michael Bess", History of the Present 4 (Spring 1988), p. 11.

36. Michel Foucault, "Truth and Power". In Vincent B. Leitch, (ed), The Norton Anthology of Theory and Criticism, New York \& London, W.W. Norton \& Company, 2001, p. 1670.

\section{ABSTRACTS}

Through a study of female mentally ill characters in the drama of Brian Friel, this article explores the links between gender, societal pressures and repression which dominate the attitude towards mental illness in an Irish context. By exploring characters through the lens of theorists such as Louis Althusser, Michel Foucault and Martin Heidegger, the way in which psychiatry, coupled with an Irish identification with Catholic guilt, served as a means of social control in the twentieth century can be unveiled.

En étudiant les personnages féminins qui souffrent de maladies mentales dans le théâtre de Brian Friel, cet article analyse les liens entre genre, pressions sociales et répression qui prédominent dans l'attitude envers la maladie mentale dans le contexte irlandais. Envisageant les personnages à travers le prisme de théoriciens tels que Louis Althusser, Michel Foucault et Martin Heidegger, il s'efforce de mettre à jour la manière dont la psychiatrie, couplée avec un sentiment de culpabilité catholique propre aux Irlandais, a servi de moyen de contrôle au vingtième siècle. 
INDEX

Mots-clés: maladie mentale, femmes et féminité, littérature et psychanalyse, rôle social de l'artiste, Friel Brian

Keywords: mental illness, literature and psychoanalysis, Friel Brian, social role of the artist, women and femininity

\section{AUTHOR}

\section{MICHELLE KENNEDY}

Mary Immaculate College, University of Limerick 